Article

\title{
A Three-Step, Gram-Scale Synthesis of Hydroxytyrosol, Hydroxytyrosol Acetate, and 3,4-Dihydroxyphenylglycol
}

\author{
Amalia D. Kalampaliki ${ }^{1}$, Vassiliki Giannouli ${ }^{1}{ }^{1}$, Alexios-Leandros Skaltsounis ${ }^{2}$ and \\ Ioannis K. Kostakis 1 ,*(D) \\ 1 Division of Pharmaceutical Chemistry, Department of Pharmacy, \\ National and Kapodistrian University of Athens, Panepistimiopolis-Zografou, 15771 Athens, Greece; \\ akalampa@pharm.uoa.gr (A.D.K.); v_giannouli@yahoo.gr (V.G.) \\ 2 Division of Pharmacognosy \& Natural Product Chemistry, Department of Pharmacy, \\ National and Kapodistrian University of Athens, Panepistimiopolis-Zografou, 15771 Athens, Greece; \\ skaltsounis@pharm.uoa.gr \\ * Correspondence: ikkostakis@pharm.uoa.gr; Tel.: +30-21-07274212; Fax: +30-21-07274727
}

Received: 24 July 2019; Accepted: 3 September 2019; Published: 5 September 2019

check for updates

\begin{abstract}
Hydroxytyrosol and two other polyphenols of olive tree, hydroxytyrosol acetate and 3,4-dihydroxyphenylglycol, are known for a wide range of beneficial activities in human health and prevention from diseases. The inability to isolate high, pure amounts of these natural compounds and the difficult and laborious procedures for the synthesis of them led us to describe herein an efficient, easy, cheap, and scaling up synthetic procedure, from catechol, via microwave irradiation.
\end{abstract}

Keywords: hydroxytyrosol; hydroxytyrosol acetate; 3,4-dihydroxyphenylglycol; large scale synthesis; microwave irradiation; nutraceutical

\section{Introduction}

Polyphenols are a wide family of compounds found in plant-based foods, such as cranberries, grapes, olives, and walnuts, and have many diverse biological activities. One of the most important components of the polyphenol family is hydroxytyrosol (HT), a simple o-diphenol found in leaves and fruits of olive tree, virgin olive oil, as well as its wastewaters. It is derived from the hydrolysis of oleuropein, during the maturation of olives, storage of oil, and preparation of table olives. Two other important polyphenols of olive tree are hydroxytyrosol acetate and 3,4-dihydroxyphenylglycol (DHPG) (Figure 1).

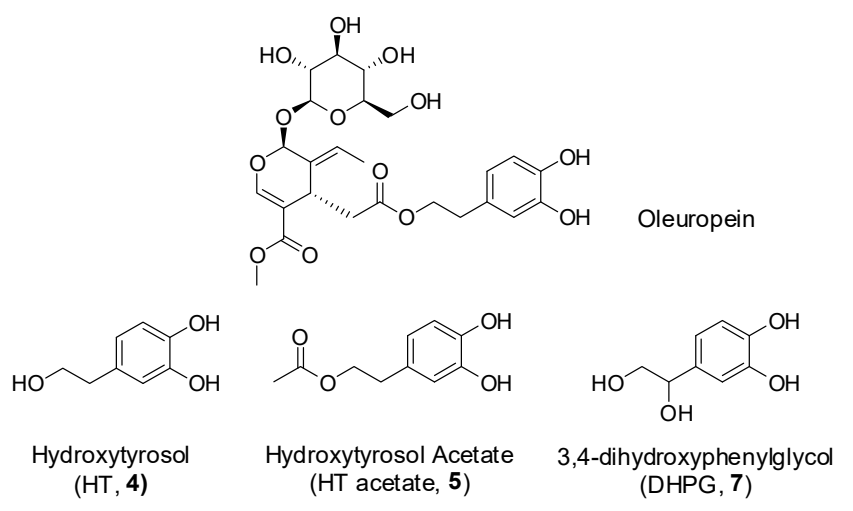

Figure 1. Major polyphenols of olive tree. 
The high interest concerning these compounds focuses on their involvement in many aspects of human health [1-3]. HT function as an efficient free radical scavenger [4-8] and metal ion chelator, such as $\mathrm{Cu}$ and $\mathrm{Fe}$, which catalyze free radical generation, to lower hydroxyl radical formation [9]. This activity can be ascribed to the electron donating ability of the o-hydroxyl groups and subsequent formation of intramolecular hydrogen bonds with free radicals [10,11]. HT effectively permeates cell membranes via passive diffusion mechanisms and counteracts the cytotoxic effects of free radicals, which are formed as a result of metabolic processes in the organism [12].

There are clear epidemiological and biochemical evidence indicating that HT possesses a cardioprotective effect, reducing the risk of coronary heart disease and atherosclerosis, through inhibition of the LDL oxidation and platelet aggregation [13-17]. The European Food Safety Authority (EFSA) has endorsed the claim that consumption of olive oil polyphenols (standardized by the content of HT and its derivatives) contributes to the protection of blood lipids from oxidative damage. The panel considers that in order to bear the claim, $5 \mathrm{mg}$ of HT and its derivatives should be consumed daily $[18,19]$. Additionally, during 2017, EFSA also confirmed that synthetic HT can be added in formulas for supplementary dietary with no difference from the natural compound [20].

Accumulating evidence associate HT with protection against the development of aging, which is intimately connected with its antioxidant [21] and anti-inflammatory activity [22,23]. Additionally, HT exerts anticancer effects through the activation of molecular signaling pathways leading to apoptosis and growth arrest in several tumor cell lines in vitro [4,5,24]. Furthermore, evidence has shown that HT interacts with pro-angiogenic growth factors, i.e., VEGF, exerting its potential anti-angiogenic activity $[25,26]$.

Due to the implication of oxidative stress and generation of reactive oxygen species in the aggregation of beta-amyloid peptide and tau protein, it is proposed that HT may offer a protective or therapeutic alternative against Alzheimer's disease [27] and other neurodegenerative diseases, such as Huntington's Disease [28], multiple scleroses [29], and Parkinson's Disease [30].

On the other hand, many findings suggest that HT protects against macular degeneration, reducing the oxidative stress in the epithelial cells of the retina, occurred by the accumulation of acrolein [31,32]. Moreover, this polyphenol seems to interact with the formation of bones and the preservation of the bone mineral density, resulting in positive effects against osteoporosis and bone loss [33]. It is imperative to notice that HT is non-genotoxic and non-mutagenic even at very high doses [34-36], and a no observed adverse effects level (NOAEL) of $500 \mathrm{mg} / \mathrm{kg} /$ day has been reported [37].

Regarding HT acetate, its antioxidant activity is much higher than that of a-tocopherol and oleuropein, but similar to HT [38]. Thus, the applications of HT could be extended using the lipophilic HT acetate which shows good solubility in oils and emulsions and could be used for controlled release of HT when needed, through its hydrolysis from lipases $[39,40]$. Additionally, DHPG has potent antioxidant $[41,42]$ and antimicrobial activity [43,44], however, there are limited studies regarding its isolation from olive tree and its activity, probably because this polyphenol is water soluble and extremely unstable under alkali treatment.

Due to the variety of the biological activities and excellent safety profile, HT, HT acetate, and DHPG are currently three of the most actively investigated natural polyphenols and could be essential supplements in the pharmaceutical and nutraceutical industry for the treatment and prevention of cardiovascular diseases, reduction of hypertension, carcinogenesis, atherosclerosis, and many other uses [45]. Additionally, HT and HT acetate could be used in the dermocosmetic industry for the protection of skin from oxidative stress or used as a preservative in the food industry [46].

\section{Results and Discussion}

The great interest of this high-added value natural compound triggered the development of various protocols in order to recover HT from olive industry wastewaters, but usually, it is isolated as a mixture with other phenolic compounds. Additionally, a few procedures describe the isolation of HT through the hydrolysis of oleuropein, a natural compound found mainly in olive tree leaves and 
other sources such as Ligustrum Vulgare [47-51]. Nevertheless, these approaches, although eco-friendly, are costly, often require the use of harmful solvents in extensive amount and usually result in low yield.

Due to the described problems, there has been a growing interest in developing an efficient synthetic route in order to obtain pure HT, but the synthesis is problematic since this compound is relatively soluble in water and polar organic solvents, therefore, the complete isolation through extraction from the reaction media is difficult [52]. Furthermore, HT is easily oxidized and relatively unstable during silica gel purifications and long-term storage [52]; thus adequate precautions must be taken (acid $\mathrm{pH}$ and absence of oxidants are crucial), concerning the synthesis and purification. Numerous synthetic approaches (more than 85 references in Reaxys database and 18 patents) [46-48,50-69] for the synthesis of HT have been described; however all these methods appear to have many disadvantages, i.e., low yields, laborious purifications, high cost, and many byproducts (Figure 2). The starting material for most of these synthetic procedures is tyrosol, through an oxidative procedure $[51,57-59,62,64,69]$, though, the major disadvantage of the abovementioned approaches consists mainly of the use of non-eco-friendly oxidative reactants and the relatively high price of tyrosol. Alternatively, the synthesis of HT has been presented by the reduction of 3,4-dihydroxyphenylacetic acid but the commercial price of the acid (or the price of the corresponding nitrile) is too high $[48,52,60,66]$. Additionally, the isolation of HT from the reaction media is difficult (because of the water solubility), thus the overall yield is often low. Interestingly, only three synthetic approaches use catechol as starting material, even though this molecule is 6400-fold cheaper than tyrosol (Sigma-Aldrich 2019) (Table 1).

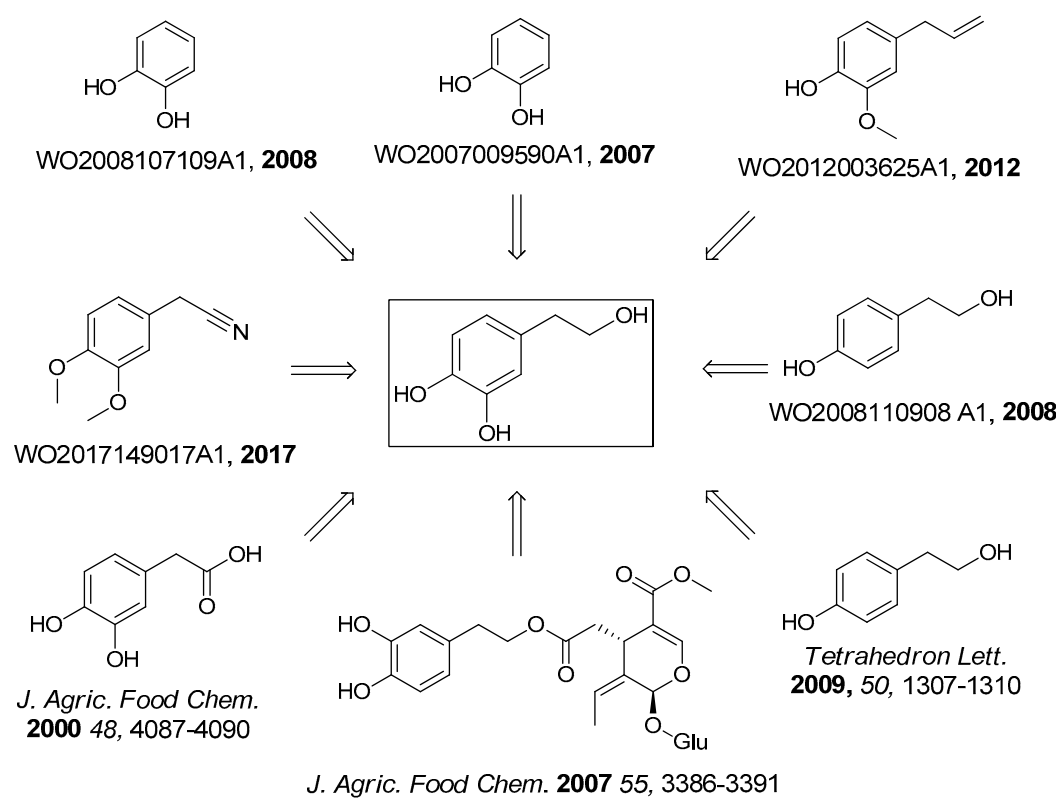

Figure 2. Synthetic approaches for hydroxytyrosol.

Concerning the synthesis of HT acetate, several synthetic procedures have been described, such as selective transesterification of the primary hydroxyl using suitable Lewis acids or protection of the phenolic hydroxyls before the acetylation [38,46,52,57-59,62,64,67-73]. Nevertheless, all of the above procedures are problematic since they use tyrosol or HT as staring material, two expensive compounds. Also, referring to the protection/deprotection approach, many steps are involved, thus the overall yield is relatively low. Regarding the synthesis of DHPG, only one synthetic procedure has been described with many steps, low yield, and vigorous conditions [74].

Prompted by the above, herein we described a simple and efficient synthesis of HT, with inexpensive catechol as staring material, without using extreme experimental conditions or laborious purifications. Additionally, the synthesis of HT acetate and DHPG was illustrated by engaging an intermediate from the procedure of HT synthesis. 
Table 1. Comparison of the methodologies for the preparation of hydroxytyrosol (HT), HT Acetate and 3,4-dihydroxyphenylglycol (DHPG).

\begin{tabular}{|c|c|c|c|c|c|}
\hline $\mathbf{A} / \mathbf{A}$ & Reference $^{a}$ & Starting Material & Short Description & Steps & $\begin{array}{c}\text { Overall } \\
\text { Yield (\%) }\end{array}$ \\
\hline \multicolumn{6}{|c|}{ Synthesis of Hydroxytyrosol } \\
\hline 1 & This Work & \multirow{4}{*}{$\mathrm{OH}$} & & 3 & 85 \\
\hline 2 & WO2007/009590A1 [63] & & $\begin{array}{l}\text { Synthesis via preparation of } \\
\text { 3,4-dihydroxymandelic acid and reduction } \\
\text { with } \mathrm{Pd} / \mathrm{C} \text { to afford 3,4-dihydroxyphenylacetic } \\
\text { acid, which upon reduction with } \mathrm{LiAlH}_{4} \\
\text { resulted to HT. }\end{array}$ & 4 & 57 \\
\hline 3 & WO2008/107109A1 [54] & & $\begin{array}{l}\text { Synthesis through chloroacetylation and } \\
\text { reduction over } \mathrm{Pd} / \mathrm{C} \text {. }\end{array}$ & 3 & 56 \\
\hline 4 & $\begin{array}{l}\text { Chem. Sus. Chem. } \\
\text { 2018, 11, 2202-2210 [53] }\end{array}$ & & $\begin{array}{l}\text { Synthesis through preparation of } \\
\text { 3,4-dihydroxymandelic acid and } \\
\text { hydrogenation with } \mathrm{Pd} / \mathrm{C} \text {. }\end{array}$ & 2 & 30 \\
\hline 5 & $\begin{array}{l}\text { Synth. Commun. } \\
2007,37,4245-4252[58]\end{array}$ & \multirow{7}{*}{$\mathrm{HO}^{-}$} & $\begin{array}{l}\text { Synthesis through oxidative bromination of } \\
\text { tyrosol and subsequent } \\
\text { methoxylation/deprotection. }\end{array}$ & 6 & 67 \\
\hline 6 & $\begin{array}{l}\text { Bioorg. Chem. } \\
\text { 2007, 35, 137-152 [69] }\end{array}$ & & Enzymatic synthesis with tyrosinase. & 1 & 95 \\
\hline 7 & WO2008/110908A1 [64] & & $\begin{array}{l}\text { Selective oxidative hydroxylation of protected } \\
\text { tyrosol by Dess Martin reagent followed } \\
\text { by deprotection. }\end{array}$ & 3 & 40 \\
\hline 8 & $\begin{array}{l}\text { J. Agric. Food Chem. } \\
2008,56,8897-8904[57]\end{array}$ & & $\begin{array}{l}\text { Selective oxidative hydroxylation of protected } \\
\text { tyrosol by Dess Martin periodinane. }\end{array}$ & 3 & 67 \\
\hline 9 & $\begin{array}{l}\text { Tetrahedron Lett. } \\
\text { 2009, 50, 1307-1310 [62] }\end{array}$ & & $\begin{array}{l}\text { Selective oxidative hydroxylation of protected } \\
\text { tyrosol by polymer-supported } \\
\text { 2-iodoxybenzoic acid. }\end{array}$ & 1 & quant. \\
\hline 10 & US2009/0023815A1 [51] & & $\begin{array}{l}\text { Enzymatic hydroxylation of tyrosol with } \\
\text { tyrosinase. }\end{array}$ & 1 & 20 \\
\hline 11 & $\begin{array}{l}\text { Tetrahedron Lett. } \\
\text { 2011, 52, 4938-4940 [59] }\end{array}$ & & $\begin{array}{l}\text { Synthesis through selective formylation and } \\
\text { Baeyer-Villiger oxidation. }\end{array}$ & 4 & 59 \\
\hline 12 & $\begin{array}{l}\text { J. Agric. Food Chem. } \\
1999,47,1745-1748[48]\end{array}$ & & Reduction via $\mathrm{LiAlH}_{4}$ & 1 & 79 \\
\hline 13 & $\begin{array}{l}\text { J. Agric. Food Chem. } \\
2000,48,4087-4090[60]\end{array}$ & & $\begin{array}{l}\text { Reduction via } \mathrm{LiAlH}_{4} \text { or } \\
\text { tetrabutylammonium boronate }\end{array}$ & 1 & 45 \\
\hline 14 & $\begin{array}{l}\text { Molecules, } \\
2007,12,1762-1770[52]\end{array}$ & & $\begin{array}{l}\text { Reduction of protected } \\
\text { 3,4-dihydroxyphenylacetic acid via } \mathrm{LiAlH}_{4} \text { and } \\
\text { deprotection via Amberlyst } 15 \text {. }\end{array}$ & 1 & 80 \\
\hline 15 & WO2017/149017A1 [66] & & $\begin{array}{l}\text { Preparation through deprotection, hydrolysis, } \\
\text { and reduction of the resulting acid via } \mathrm{LiAlH}_{4} \text {. }\end{array}$ & 4 & 36 \\
\hline 16 & WO2012/003625A1 [65] & & $\begin{array}{l}\text { Preparation through ozonolysis and } \\
\text { deprotection via } \mathrm{AlCl}_{3} / \mathrm{EtSH} \text { system. }\end{array}$ & 3 & 75 \\
\hline 17 & $\begin{array}{l}\text { J. Agric. Food Chem. } \\
2007,55,3386-3391[50]\end{array}$ & Oleuropein & $\begin{array}{l}\text { Preparation through basic hydrolysis of } \\
\text { protected oleuropein and deprotection via } \\
\text { Amberlyst } 15 .\end{array}$ & 1 & 11 \\
\hline 18 & $\begin{array}{l}\text { Mediterr. J. Chem. } \\
2018,7,217-222 \text { [49] }\end{array}$ & Oleuropein (pure) & $\begin{array}{l}\text { Preparation through acidic hydrolysis of } \\
\text { oleuropein obtained from Ligustrum Vulgare. }\end{array}$ & 1 & 73 \\
\hline & & Synthesis of & ydroxytyrosol Acetate & & \\
\hline 1 & This Work & & & 3 & 73 \\
\hline 2 & $\begin{array}{l}\text { Synth. Commun. } \\
2007,37,4245-4252 \text { [58] }\end{array}$ & OH & $\begin{array}{l}\text { Synthesis through oxidative bromination of } \\
\text { tyrosol and subsequent methoxylation, } \\
\text { bis-acetylation and selective deprotection. }\end{array}$ & 5 & 70 \\
\hline 3 & WO2008/110908A1 [64] & & $\begin{array}{l}\text { Selective oxidative hydroxylation of tyrosol } \\
\text { acetate by Dess Martin reagent. }\end{array}$ & 3 & 40 \\
\hline 4 & $\begin{array}{l}\text { J. Agric. Food Chem. } \\
2008,56,8897-8904[57]\end{array}$ & & $\begin{array}{l}\text { Selective oxidative hydroxylation of tyrosol } \\
\text { acetate by Dess Martin periodinane. }\end{array}$ & 2 & 76 \\
\hline 5 & $\begin{array}{l}\text { Tetrahedron Lett. } \\
2011,52,4938-4940 \text { [59] }\end{array}$ & & $\begin{array}{l}\text { Synthesis through selective formylation and } \\
\text { Baeyer-Villiger oxidation of tyrosol. acetate }\end{array}$ & 4 & 66 \\
\hline 6 & $\begin{array}{l}\text { Bioorg. Med. Chem. } \\
\text { 2015, 23, 5345-5351 [68] }\end{array}$ & & $\begin{array}{l}\text { Enzymatic hydroxylation of tyrosol with } \\
\text { tyrosinase subsequent esterification via Candida } \\
\text { antarctica lipase. }\end{array}$ & 1 & 98 \\
\hline
\end{tabular}

${ }^{a}$ Each number in the brackets represents the number in the reference section. 
Table 1. Cont

\begin{tabular}{|c|c|c|c|c|c|}
\hline A/A & Reference $^{a}$ & Starting Material & Short Description & Steps & $\begin{array}{c}\text { Overall } \\
\text { Yield (\%) }\end{array}$ \\
\hline 7 & $\begin{array}{l}\text { J. Agric. Food Chem. } \\
2001,49,2480-2485 \text { [38] }\end{array}$ & \multirow{4}{*}{$\mathrm{OH}_{\mathrm{OH}}$} & $\begin{array}{l}\text { Synthesis through dibenzyloxy-HT, acetylation } \\
\text { and subsequent deprotection. }\end{array}$ & 3 & 25 \\
\hline 8 & US2003/0236202 [73] & & $\begin{array}{l}\text { Selective esterification with } \mathrm{K}_{2} \mathrm{CO}_{3} \text { and } \\
\text { tetrabutylammonium hydrogen sulfate. }\end{array}$ & 1 & 57 \\
\hline 9 & WO2004/005237A1 [71] & & $\begin{array}{l}\text { Selective transesterification via ethylacetate } \\
\text { and p-toluenesulfonic acid. }\end{array}$ & 1 & 86 \\
\hline 10 & EP1541544A1 [72] & & $\begin{array}{l}\text { Enzymatic esterification with porcine } \\
\text { pancreatic lipase. }\end{array}$ & 1 & 86 \\
\hline \multicolumn{6}{|c|}{ Synthesis of DHPG } \\
\hline 1 & This Work & & & 3 & 70 \\
\hline 2 & $\begin{array}{l}\text { J. Med. Chem. } \\
\text { 1963, 607-608 [74] }\end{array}$ & & $\begin{array}{l}\text { Synthesis via hydrolysis of } \\
\text { 3,4-dibenzyloxymandelonitrile, reduction of } \\
\text { the resulting acid via } \mathrm{LiAlH}_{4} \text { and deprotection } \\
\text { via } \mathrm{Pd} / \mathrm{C} \text {. }\end{array}$ & 4 & 20 \\
\hline
\end{tabular}

${ }^{a}$ Each number in the brackets represents the number in the reference section.

To overcome the solubility and stability limitations of HT, we envisioned a three-step synthetic procedure depicted in Scheme 1. The first step of the synthesis involved Friedel-Craft acylation of catechol (1) with chloroacetyl chloride in nearly quantitative yield. The preparation of chloride $\mathbf{2}$ has been previously reported through many different procedures [75,76]; however, the method reported herein, via microwave irradiation, was straightforward, simple, high yielding, and cost-effective. Thus, after vacuum evaporation of the excess of $\mathrm{POCl}_{3}$ and trituration with water, the crude product was used without any further purification. It should be noted that the evaporation of the excess of $\mathrm{POCl}_{3}$ before the trituration with water was crucial, otherwise, and if the reaction mixture is poured into ice-water (an experimental usually used for reactions with $\mathrm{POCl}_{3}$ ), the overall yield is remarkably reduced (about $40 \%$ ) even after extraction of the reaction media.<smiles>CC(C)(C)C(=O)c1ccc(O)c(O)c1</smiles><smiles>CCOC(CO)c1ccc(O)c(O)c1</smiles><smiles>C=C(CO)c1ccc(O)c(O)c1</smiles><smiles>CC(=O)OCCc1ccc(O)c(O)c1</smiles>

8 6<smiles>OCC(O)c1ccc(O)c(O)c1</smiles>

Scheme 1. Reagents and conditions: (a) chloroacetyl chloride, $\mathrm{POCl}_{3}, 105^{\circ} \mathrm{C}, 150 \mathrm{~W}$; (b) $\mathrm{Et}_{3} \mathrm{SiH}$, $\mathrm{CF}_{3} \mathrm{CO}_{2} \mathrm{H}$ or $\mathrm{BF}_{3} . \mathrm{Et}_{2} \mathrm{O}, 25^{\circ} \mathrm{C}$; (c) $\mathrm{H}_{2} \mathrm{O}, 100{ }^{\circ} \mathrm{C}, 100 \mathrm{~W}$; (d) $\mathrm{CH}_{3} \mathrm{CO}_{2} \mathrm{~K}, \mathrm{DMF}$ dry, $70{ }^{\circ} \mathrm{C}$; (e) $\mathrm{H}_{2}, \mathrm{Pd} / \mathrm{C}$, $\mathrm{HClO}_{4}$, abs. ethanol; (f) $\mathrm{H}_{2}, \mathrm{Pd} / \mathrm{C}$, methanol. 
The next step concerns the reduction of the carbonyl group; still all the initial attempts, under several conditions, provided complex mixtures. Among the variety of conditions used for the reduction of compound 2, only the reduction with triethylsilane in the presence of a Lewis acid gave the desired chloro compound 3 [77-80]. More precisely, of the various Lewis acids and reaction conditions that were tested, the use of a fourfold excess of trifluoroacetic acid or a fivefold excess of boron trifluoride etherate and a twofold excess of triethylsilane derived the desirable catechol 3 in $95 \%$ or $92 \%$, respectively. The reaction proceeded smoothly with no formation of byproducts. It is remarkable to note that the crude of the reaction was readily purified, after vacuum evaporation of the volatiles, by just trituration with boiling cyclohexane and vacuum evaporation of the solvent.

Finally, chloride 3 was readily converted to the corresponding HT (4) upon hydrolysis with distilled water, via microwave heating in a Milestone Start E apparatus. Reaction conditions were optimized, varying applied power and temperature, measured by fiber optic contact thermometer. The best results were obtained using programmed irradiation at 700 watts, at $101^{\circ} \mathrm{C}$, at open vessel conditions, and HT was obtained in $>92 \%$ yield.

It is important to note that by the above-mentioned conditions, because of the absence of basic media (actually the reaction media was acidic due to the hydrochloric acid produced by the reaction) or oxidants, the reaction proceeded readily. Furthermore, the isolation was very simple, and no chromatography purification was needed. After completion of the reaction, the mixture was extracted with dichloromethane, and the aqueous phase was vacuum evaporated at low temperature or lyophilized, in order to obtain pure HT. Scaling up to $10 \mathrm{~g}$ of the above-mentioned synthetic procedure afforded reproducible overall yields. Higher scale-ups, up to $120 \mathrm{~g}$ showed the same excellent results only by modifying the time reaction conditions. The final step of the hydrolysis of chloride 3 to HT (4) was also accomplished via conventional heating, but much more time was needed. In particular, the hydrolysis of $23 \mathrm{~g}$ of chloride 3 to HT (4) required $4 \mathrm{~h}$, instead of $32 \mathrm{~h}$ of conventional heating. Additionally, the yield of the reaction was lower ( $65 \%$ vs. $94.8 \%$ by MW heating) probably due to the instability of HT. Most importantly, the purification of HT, synthesized by MW-assisted hydrolysis, was very simple allowing the overall workup simplification, whilst the same purification of the product, of the conventional heating procedure, was laborious.

The overall yield of proposed approach was up to $85 \%$, with only three steps involved, whilst the purification was easy with no silica gel chromatography needed (Table 1). Nevertheless, the main advantage of the procedure concerned the use of catechol as staring material, an inexpensive compound, instead of tyrosol, which is usually used, and the reproducibility of the method, even in scale-up conditions. There are only three other cases in which catechol is used as starting material, though, the developed approach possessed the highest yield, with only three steps involved. Besides, only limited amount of solvents, for the reaction and the purification procedures, were needed.

Taking advantage of the intermediate 3, we were also able to prepare HT acetate (5), via a one-step reaction, upon treatment with potassium acetate in dry DMF at $70{ }^{\circ} \mathrm{C}$, which yielded up to $85 \%$ (Scheme 1). It is important to notice that the presented procedure was straightforward, with no protection of the phenolic groups needed. The overall yield of the procedure was up to $73 \%$, with minimum purifications, since the only silica gel column chromatography was performed on the final step. Into the best of our knowledge, this was the only approach that used catechol for the synthesis of HT-acetate, since all the other procedures use tyrosol or HT as starting material (Table 1). In addition, we can assert that the presented procedure for the synthesis of HT acetate could be used for the synthesis of various HT lipophilic esters, in order to study their biological activity.

Regarding the synthesis of 3,4-dihydroxyphenylglycol (7), a slightly different methodology was developed, which involved the initial hydrolysis of compound 2 to provide alcohol $\mathbf{6}$. Although this hydrolysis is already described in the literature via $\mathrm{HCOONa} / \mathrm{HCOOH}$ system [40], in our hands proceeded almost quantitively, by microwave heating, in distilled water. The reaction was scalable up to grams, without any by-products formed, while the purification was very simple, by trituration with ethyl acetate. Finally, target DHPG (7) was prepared through catalytic hydrogenation in methanol, 
in an $82 \%$ overall yield. The overall yield of the proposed procedure was up to $70 \%$, far better than the previous procedure, with only three steps involved (Table 1) [74]. Interestingly, reduction of keto compound 6 over palladium on activated carbon, in the presence of a few drops of perchloric or hydrochloric acid, in abs. ethanol, afforded ether 8 [81], presumably through protonation of the intermediate alcohol and subsequent nucleophilic substitution by ethanol. It should be noted that this compound, even as a racemic mixture, is very interesting, since it is a stable form of DHPG, with better lipophilicity, and could be useful to study the therapeutic role and potentiality of DHPG.

\section{Materials and Methods}

\section{General Experimental Procedures}

All chemicals were purchased from Alfa Aesar (Ward Hill, MA, USA). Melting points were determined on a Büchi apparatus and were uncorrected. ${ }^{1} \mathrm{H} N M R,{ }^{13} \mathrm{C}$ NMR and 2D spectra were recorded on a Bruker Avance III 600 spectrometer (Bruker BioSpin GmbH, Rheinstetten, Germany), in deuterated solvents and were referenced to TMS ( $\delta$ scale). The signals of ${ }^{1} \mathrm{H}$ and ${ }^{13} \mathrm{C}$ spectra were unambiguously assigned by using $2 \mathrm{D}$ NMR techniques: ${ }^{1} \mathrm{H}^{1} \mathrm{H}$ COSY, HMQC, and HMBC. Flash chromatography was performed on Merck silica gel $60(0.040-0.063 \mathrm{~mm})$. Analytical thin layer chromatography (TLC) was carried out on pre-coated $(0.25 \mathrm{~mm})$ Merck silica gel F-254 plates (Merck KGa, Darmstadt, Germany). Mass spectra were recorded with a QqToF Premier MicroMass MS technology (Waters, Manchester, UK). The purity of all the synthesized compounds was $>95 \%$, determined by ${ }^{1} \mathrm{H}$ NMR. Microwave experiments were performed on Milestone Start E apparatus (Milestone Srl, Bergamo, Italy). ${ }^{1} \mathrm{H}$ and ${ }^{13} \mathrm{C}-\mathrm{NMR}$ spectra are available online as Supplementary Materials. For a schematic overview and detailed steps, see Scheme 1.

2-chloro-1-(3,4-dihydroxyphenyl)ethanone (2): A solution of catechol 1 (100 g, $0.94 \mathrm{~mol}$ ) and chloroacetyl chloride $(84.9 \mathrm{~mL}, 1.04 \mathrm{~mol})$ in phosphoryl chloride $(264.2 \mathrm{~mL}, 2.82 \mathrm{~mol})$ was stirred under microwave irradiation $(450 \mathrm{~W})$ at $105^{\circ} \mathrm{C}$ for $3 \mathrm{~h}$. After completion of the reaction, the excess of phosphoryl chloride was vacuum evaporated, poured into ice-water, and the resulting solid product was filtered off and dried to afford $162.6 \mathrm{~g}(93 \%)$ of the title compound, which was used for the next step without any further purification. ${ }^{1} \mathrm{H}$ NMR (600 MHz, $\left.\mathrm{CD}_{3} \mathrm{OD}\right) \delta: 7.42-7.43(\mathrm{~m}, 2, \mathrm{H}-3, \mathrm{H}-5), 6.84(\mathrm{~d}, 1, J=8.2 \mathrm{~Hz}$, $\mathrm{H}-6), 4.80\left(\mathrm{~s}, 2, \mathrm{CH}_{2}\right) .{ }^{13} \mathrm{C} \mathrm{NMR}\left(151 \mathrm{MHz}, \mathrm{CD}_{3} \mathrm{OD}\right) \delta: 192.23\left(\mathrm{COCH}_{2}\right), 152.95(\mathrm{C}-3), 146.71(\mathrm{C}-4)$, 127.87 (C-1), 123.58 (C-6), 116.24 (C-5), 115.99 (C-2), $46.87\left(\mathrm{CH}_{2} \mathrm{Cl}\right)$. (-) ESI QqToF (m/z): Calcd. for $\mathrm{C}_{8} \mathrm{H}_{6} \mathrm{ClO}_{3}^{-}:[\mathrm{M}-\mathrm{H}]^{-}$185.0011, found 185.0004.

4-(2-chloroethyl)benzene-1,2-diol (3): To a suspension of chloride $2(80.42 \mathrm{~g}, 0.43 \mathrm{~mol}$ ) in trifluoroacetic acid $(165.40 \mathrm{~mL}, 2.15 \mathrm{~mol})$ was added dropwise triethylsilane $(276 \mathrm{~mL}, 2.15 \mathrm{~mol})$ at $0{ }^{\circ} \mathrm{C}$, and the mixture was stirred at room temperature for $11 \mathrm{~h}$. After completion of the reaction, most of the volatiles were removed under reduced pressure, and the oily product was washed with boiling cyclohexane $(10 \times 500 \mathrm{~mL})$. The cyclohexane layer was decanted and concentrated under reduced pressure to afford $71 \mathrm{~g}(96 \%)$ of compound 3 which was used for the next step without any further purification. M.p.: 102-104 ${ }^{\circ} \mathrm{C}$ (EtOAc/n-hexane). ${ }^{1} \mathrm{H}$ NMR $\left(600 \mathrm{MHz},\left(\mathrm{CD}_{3}\right)_{2} \mathrm{CO}\right) \delta: 7.75$ (br s, 2, $\mathrm{D}_{2} \mathrm{O}$ exch., 1-OH, 2-OH), $6.76(\mathrm{~d}, 1, J=8.2 \mathrm{~Hz}, \mathrm{H}-6), 6.75(\mathrm{~s}, 1, \mathrm{H}-3), 6.60(\mathrm{dd}, 1, J=8.0,2.2 \mathrm{~Hz}, \mathrm{H}-5), 3.70\left(\mathrm{t}, 2, \mathrm{~J}=7.1 \mathrm{~Hz}, \mathrm{CH}_{2} \mathrm{Cl}\right)$, $2.90\left(\mathrm{t}, 2, J=7.1 \mathrm{~Hz}, \mathrm{CH}_{2} \mathrm{CH}_{2} \mathrm{Cl}\right) .{ }^{13} \mathrm{C}$ NMR $\left(151 \mathrm{MHz},\left(\mathrm{CD}_{3}\right)_{2} \mathrm{CO}\right) \delta: 145.80$ (C-2), 144.67 (C-1), 130.87 (C-4), 121.06 (C-5), $116.74(\mathrm{C}-6), 116.06(\mathrm{C}-3), 46.10\left(\mathrm{CH}_{2} \mathrm{Cl}\right), 39.22\left(\mathrm{CH}_{2} \mathrm{CH}_{2} \mathrm{Cl}\right)$. (-) ESI QqToF $(\mathrm{m} / \mathrm{z})$ : Calcd. for $\mathrm{C}_{8} \mathrm{H}_{8} \mathrm{ClO}_{2}^{-}$: [M - H] $]^{-}$171.0218, found 171.0224.

Hydroxytyrosol or 4-(2-hydroxyethyl)benzene-1,2-diol (4): A suspension of chloride 3 ( $23 \mathrm{~g}, 0.13 \mathrm{~mol}$ ) in distilled water $(200 \mathrm{~mL})$ was stirred under microwave irradiation $(700 \mathrm{~W})$ at $101^{\circ} \mathrm{C}$ for $4 \mathrm{~h}$. After completion of the reaction, the mixture was washed with dichloromethane $(2 \times 100 \mathrm{~mL})$ and water was removed under reduced pressure or lyophilization to afford $19 \mathrm{~g}(94.8 \%)$ of the title compound as an oil. ${ }^{1} \mathrm{H}$ NMR $\left(600 \mathrm{MHz}, \mathrm{CD}_{3} \mathrm{OD}\right) \delta: 6.63(\mathrm{~d}, 1, J=8.2 \mathrm{~Hz}, \mathrm{H}-6), 6.61(\mathrm{~d}, 1, J=2.2 \mathrm{~Hz}, \mathrm{H}-3), 6.48(\mathrm{dd}$, $1, J=8.2,2.2 \mathrm{~Hz}, \mathrm{H}-5), 3.63\left(\mathrm{t}, 2, J=7.1 \mathrm{~Hz}, \mathrm{CH}_{2} \mathrm{OH}\right), 2.62\left(\mathrm{t}, J=7.1 \mathrm{~Hz}, 2, \mathrm{CH}_{2} \mathrm{CH}_{2} \mathrm{OH}\right) .{ }^{13} \mathrm{C}-\mathrm{NMR}$ 
(151 MHz, CD $\left.{ }_{3} \mathrm{OD}\right)$ 8: 146.15 (C-2), 144.62 (C-1), 131.80 (C-4), 121.21 (C-5), 117.07 (C-6), 116.31 (C-3), $64.59\left(\mathrm{CH}_{2} \mathrm{OH}\right), 39.65\left(\mathrm{CH}_{2} \mathrm{CH}_{2} \mathrm{OH}\right)$. (-) ESI QqToF $(\mathrm{m} / \mathrm{z})$ : Calcd. for $\mathrm{C}_{8} \mathrm{H}_{9} \mathrm{O}_{3}{ }^{-}:[\mathrm{M}-\mathrm{H}]^{-}$153.0557, found 153.0551 .

Hydroxytyrosol acetate or 2-(3,4-dihydroxyphenyl)ethyl acetate (5): A solution of chloride 3 (12.0 g, $69.2 \mathrm{mmol})$ and $\mathrm{CH}_{3} \mathrm{COOK}(27.23 \mathrm{~g}, 276.9 \mathrm{mmol})$ in dry DMF $(60 \mathrm{~mL})$ was stirred at $80^{\circ} \mathrm{C}$ for $12 \mathrm{~h}$. After completion of the reaction, the excess of DMF was removed under reduced pressure and the crude product was purified by column chromatography (silica gel), eluted by a system of cyclohexane/ethyl acetate $3 / 1$, to afford $11.1 \mathrm{~g}(82 \%)$ of the title compound 5. M.p.: $81-83{ }^{\circ} \mathrm{C}\left(\mathrm{CH}_{2} \mathrm{Cl}_{2} / \mathrm{CCl}_{4}\right) .{ }^{1} \mathrm{H} \mathrm{NMR}$ $\left(600 \mathrm{MHz}, \mathrm{CDCl}_{3}\right) \delta: 6.78(\mathrm{~d}, 1, J=8.2 \mathrm{~Hz}, \mathrm{H}-5), 6.72(\mathrm{~d}, 1, J=2.2 \mathrm{~Hz}, \mathrm{H}-2), 6.59(\mathrm{dd}, 1, J=8.2,2.2 \mathrm{~Hz}$, $\mathrm{H}-6), 4.22\left(\mathrm{t}, 2, J=7.1 \mathrm{~Hz}, \mathrm{CH}_{2} \mathrm{O}\right), 2.78\left(\mathrm{t}, 2, J=7.1 \mathrm{~Hz}, \mathrm{CH}_{2} \mathrm{CH}_{2} \mathrm{O}\right), 2.04\left(\mathrm{~s}, 3, \mathrm{COCH}_{3}\right) .{ }^{13} \mathrm{C} \mathrm{NMR}$ $\left(151 \mathrm{MHz}, \mathrm{CDCl}_{3}\right)$ 8: 172.61 (CO), 143.91 (C-3), 142.61 (C-4), 130.32 (C-1), 121.25 (C-6), 116.01 (C-5), $115.55(\mathrm{C}-2), 65.71\left(\mathrm{CH}_{2} \mathrm{O}\right), 34.36\left(\mathrm{CH}_{2} \mathrm{CH}_{2} \mathrm{O}\right), 21.12\left(\mathrm{CH}_{3}\right)$. (-) ESI QqToF (m/z): Calcd. for $\mathrm{C}_{10} \mathrm{H}_{11} \mathrm{O}_{4}{ }^{-}$: $[\mathrm{M}-\mathrm{H}]^{-}$195.0663, found 195.0655.

1-(3,4-dihydroxyphenyl)-2-hydroxyethanone (6): This compound was synthesized with an analogous procedure as described for compound 4, starting from the chloride 2, in 91\% yield. ${ }^{1} \mathrm{H} \mathrm{NMR}(600 \mathrm{MHz}$, $\left.\left(\mathrm{CD}_{3}\right)_{2} \mathrm{CO}\right) \delta: 7.48(\mathrm{~d}, 1, J=2.2 \mathrm{~Hz}, \mathrm{H}-2), 7.44(\mathrm{dd}, 1, J=8.2,2.2 \mathrm{~Hz}, \mathrm{H}-6), 6.94(\mathrm{~d}, 1, J=8.2 \mathrm{~Hz}, \mathrm{H}-5)$, $4.76\left(\mathrm{~s}, 2, \mathrm{CH}_{2}\right) .{ }^{13} \mathrm{C}$ NMR $\left(151 \mathrm{MHz},\left(\mathrm{CD}_{3}\right)_{2} \mathrm{CO}\right) \delta: 197.81$ (CO), 151.61 (C-3), 145.95 (C-4), 127.54 (C-1), 122.16 (C-6), 115.94 (C-5), 115.28 (C-2), $65.53\left(\mathrm{CH}_{2}\right)$. (-) ESI QqToF (m/z): Calcd. for $\mathrm{C}_{8} \mathrm{H}_{7} \mathrm{O}_{4}{ }^{-}$: [M $\mathrm{H}]^{-}$167.0350, found 167.0357.

3,4-dihydroxyphenylglycol (DHPG, 7): A solution of 6 (1.4 g, $8.33 \mathrm{mmol})$ in methanol $(80 \mathrm{~mL})$ was hydrogenated in the presence of $10 \% \mathrm{Pd} / \mathrm{C}(100 \mathrm{mg})$, under a pressure of $50 \mathrm{psi}$, at room temperature for $9 \mathrm{~h}$. The resulting mixture was filtered through a Celite pad, and the filtrate was evaporated to dryness. Treatment with activated charcoal in hot methanol and filtration through a Celite pad afforded the title compound practically pure $(1.13 \mathrm{mg}, 80 \%)$. For analytical reasons, a small amount was quickly purified (due to stability reasons) by column chromatography (silica gel) using a mixture of cyclohexane/ethyl acetate $1 / 4$ as the eluent. ${ }^{1} \mathrm{H}$ NMR $\left(600 \mathrm{MHz}, \mathrm{CD}_{3} \mathrm{OD}\right) \delta: 6.83(\mathrm{~d}, 1, J=2.0 \mathrm{~Hz}$, H-2), $6.74(\mathrm{~d}, 1, J=8.2 \mathrm{~Hz}, \mathrm{H}-5), 6.68(\mathrm{~d}, 1, J=8.2 \mathrm{~Hz}, \mathrm{H}-6), 4.55\left(\mathrm{t}, 1, J=6.1 \mathrm{~Hz}, \mathrm{CHCH}_{2}\right), 3.58$ (d, 2, $\left.J=6.0 \mathrm{~Hz}, \mathrm{CHCH}_{2}\right) .{ }^{13} \mathrm{C} \mathrm{NMR}\left(151 \mathrm{MHz}, \mathrm{CD}_{3} \mathrm{OD}\right) \delta: 146.07$ (C-3), $145.72(\mathrm{C}-4), 134.72(\mathrm{C}-1), 118.98$ (C-6), $116.11(\mathrm{C}-5), 114.64(\mathrm{C}-2), 75.70\left(\mathrm{CHCH}_{2}\right), 68.69\left(\mathrm{CHCH}_{2}\right)$. (-) ESI QqToF $(\mathrm{m} / \mathrm{z})$ : Calcd. for $\mathrm{C}_{8} \mathrm{H}_{9} \mathrm{O}_{4}^{-}:[\mathrm{M}-\mathrm{H}]^{-}$169.0506, found 169.0512 .

4-(1-ethoxy-2-hydroxyethyl)benzene-1,2-diol (8): To a solution of 6 (200 mg, $1.19 \mathrm{mmol}$ ) in abs. ethanol $(20 \mathrm{~mL})$ was added $\mathrm{HClO}_{4}(100 \mu \mathrm{L})$ and the mixture was hydrogenated in the presence of $10 \% \mathrm{Pd} / \mathrm{C}$ $(20 \mathrm{mg})$, under a pressure of $50 \mathrm{psi}$, at room temperature, for $4 \mathrm{~h}$. The resulting mixture was filtered through a Celite pad and the filtrate was evaporated to dryness and the residue was purified by column chromatography (silica gel) using a mixture of cyclohexane/ethyl acetate $1 / 2$ as the eluent to afford $198 \mathrm{mg}(84 \%)$ of the title compound. ${ }^{1} \mathrm{H}$ NMR $\left(600 \mathrm{MHz},\left(\mathrm{CD}_{3}\right)_{2} \mathrm{CO}\right) \delta: 7.81$ (br s, 2, $\mathrm{D}_{2} \mathrm{O}$ exch., 1-OH, 2-OH, 6.81 (d, 1, J = 2.2 Hz, H-3), 6.78 (d, 1, J = 8.2 Hz, H-6), 6.65 (dd, 1, J = 8.2, 2.2 Hz, H-5), $4.20\left(\mathrm{~m}, 1, \mathrm{CHCH}_{2}\right), 3.54-3.60\left(\mathrm{~m}, 1, \mathrm{CHCH}_{2} \mathrm{OH}\right), 3.39-3.47\left(\mathrm{~m}, 2, \mathrm{CHCH}_{2} \mathrm{OH}, \mathrm{CH}_{2} \mathrm{CH}_{3}\right), 3.32-3.38$ (m, 1, $\left.\mathrm{CH}_{2} \mathrm{CH}_{3}\right), 1.12\left(\mathrm{t}, 3, J=7.1 \mathrm{~Hz}, \mathrm{CH}_{2} \mathrm{CH}_{3}\right) .{ }^{13} \mathrm{C} \mathrm{NMR}\left(151 \mathrm{MHz},\left(\mathrm{CD}_{3}\right)_{2} \mathrm{CO}\right) \delta: 145.83(\mathrm{C}-2)$, 145.44 (C-1), 132.74 (C-4), 119.38 (C-5), 115.85 (C-6), $114.67(\mathrm{C}-3), 83.75\left(\mathrm{CHCH}_{2}\right), 67.96\left(\mathrm{CHCH}_{2} \mathrm{OH}\right)$, $64.58\left(\mathrm{CH}_{2} \mathrm{CH}_{3}\right), 15.65\left(\mathrm{CH}_{2} \mathrm{CH}_{3}\right)$. (-) ESI QqToF (m/z): Calcd. for $\mathrm{C}_{10} \mathrm{H}_{13} \mathrm{O}_{4}{ }^{-}:[\mathrm{M}-\mathrm{H}]^{-}$197.0819, found 197.0811.

\section{Conclusions}

In summary, a new, large-scale, straightforward synthetic approach for the preparation of HT as well as HT acetate and DHPG has been described in the present work, using simple, low-cost, and scalable procedures, starting from inexpensive, commercially available catechol. The established procedure for the synthesis of HT acetate could be used for the synthesis of other lipophilic esters of 
HT. Additionally, a synthetic approach for the synthesis of compound 8 has been proposed, which could be used for the development of new lipophilic and stable analogs of DHPG. All the reactions proceeded smoothly, with no byproducts formed, while the purification of the compounds was very simple, mostly by solvent trituration. The synthetic procedures were based in microwave irradiation, which enabled more precise control of the reaction conditions and contributed to higher yields, thus, the new synthetic approaches could be an alternative for the industrial preparation of HT, HT acetate and DHPG.

Supplementary Materials: ${ }^{1} \mathrm{H}$ and ${ }^{13} \mathrm{C}-\mathrm{NMR}$ spectra are available online.

Author Contributions: The manuscript was written through contributions of all authors. All authors have given approval to the final version of the manuscript. A.D.K. and V.G. performed chemical synthesis experiments and analyzed results, I.K.K. and A.-L.S. designed chemical synthesis, analyzed results, and wrote the manuscript.

Funding: This research received no external funding.

Acknowledgments: We would like to thank E. Gikas for assistance with mass spectra analysis.

Conflicts of Interest: The authors declare no competing financial interest.

\section{References}

1. Gorzynik-Debicka, M.; Przychodzen, P.; Cappello, F.; Kuban-Jankowska, A.; Marino Gammazza, A.; Knap, N.; Wozniak, M.; Gorska-Ponikowska, M. Potential Health Benefits of Olive Oil and Plant Polyphenols. Int. J. Mol. Sci. 2018, 19, 686. [CrossRef] [PubMed]

2. Rigacci, S.; Stefani, M. Nutraceutical Properties of Olive Oil Polyphenols. An Itinerary from Cultured Cells through Animal Models to Humans. Int. J. Mol. Sci. 2016, 17, 843. [CrossRef] [PubMed]

3. Martínez, L.; Ros, G.; Nieto, G. Hydroxytyrosol: Health Benefits and Use as Functional Ingredient in Meat. Medicines 2018, 5, 13. [CrossRef] [PubMed]

4. Sirianni, R.; Chimento, A.; De Luca, A.; Casaburi, I.; Rizza, P.; Onofrio, A.; Iacopetta, D.; Puoci, F.; Andò, S.; Maggiolini, M.; et al. Oleuropein and hydroxytyrosol inhibit MCF-7 breast cancer cell proliferation interfering with ERK1/2 activation. Mol. Nutr. Food Res. 2010, 54, 833-840. [CrossRef]

5. Fabiani, R.; Fuccelli, R.; Pieravanti, F.; De Bartolomeo, A.; Morozzi, G. Production of hydrogen peroxide is responsible for the induction of apoptosis by hydroxytyrosol on HL60 cells. Mol. Nutr. Food Res. 2009, 53, 887-896. [CrossRef] [PubMed]

6. Bouallagui, Z.; Han, J.; Isoda, H.; Sayadi, S. Hydroxytyrosol rich extract from olive leaves modulates cell cycle progression in MCF-7 human breast cancer cells. Food Chem. Toxicol. 2011, 49, 179-184. [CrossRef] [PubMed]

7. Bulotta, S.; Corradino, R.; Celano, M.; D’Agostino, M.; Maiuolo, J.; Oliverio, M.; Procopio, A.; Iannone, M.; Rotiroti, D.; Russo, D. Antiproliferative and antioxidant effects on breast cancer cells of oleuropein and its semisynthetic peracetylated derivatives. Food Chem. 2011, 127, 1609-1614. [CrossRef]

8. Goya, L.; Mateos, R.; Bravo, L. Effect of the olive oil phenol hydroxytyrosol on human hepatoma HepG2 cells. Protection against oxidative stress induced by tert-butylhydroperoxide. Eur. J. Nutr. 2007, 46, 70-78. [CrossRef]

9. Tripoli, E.; Giammanco, M.; Tabacchi, G.; Di Majo, D.; Giammanco, S.; La Guardia, M. The phenolic compounds of olive oil: Structure, biological activity and beneficial effects on human health. Nutr. Res. Rev. 2005, 18, 98-112. [CrossRef]

10. Rietjens, S.J.; Bast, A.; Haenen, G.R.M.M. New insights into controversies on the antioxidant potential of the olive oil antioxidant hydroxytyrosol. J. Agric. Food Chem. 2007, 55, 7609-7614. [CrossRef]

11. De Lucia, M.; Panzella, L.; Pezzella, A.; Napolitano, A.; d'Ischia, M. Oxidative chemistry of the natural antioxidant hydroxytyrosol: Hydrogen peroxide-dependent hydroxylation and hydroxyquinone/o-quinone coupling pathways. Tetrahedron 2006, 62, 1273-1278. [CrossRef]

12. Manna, C.; Galletti, P.; Maisto, G.; Cucciolla, V.; D’Angelo, S.; Zappia, V. Transport mechanism and metabolism of olive oil hydroxytyrosol in Caco-2 cells. FEBS Lett. 2000, 470, 341-344. [CrossRef]

13. Petroni, A.; Blasevich, M.; Salami, M.; Papini, N.; Montedoro, G.F.; Galli, C. Inhibition of platelet aggregation and eicosanoid production by phenolic components of olive oil. Thromb. Res. 1995, 78, 151-160. [CrossRef] 
14. Covas, M.-I. Olive oil and the cardiovascular system. Pharmacol. Res. 2007, 55, 175-186. [CrossRef] [PubMed]

15. Covas, M.-I.; Nyyssönen, K.; Poulsen, H.E.; Kaikkonen, J.; Zunft, H.-J.F.; Kiesewetter, H.; Gaddi, A.; de la Torre, R.; Mursu, J.; Bäumler, H.; et al. The effect of polyphenols in olive oil on heart disease risk factors: A randomized trial. Ann. Intern. Med. 2006, 145, 333-341. [CrossRef] [PubMed]

16. Fitó, M.; Cladellas, M.; de la Torre, R.; Martí, J.; Alcántara, M.; Pujadas-Bastardes, M.; Marrugat, J.; Bruguera, J.; López-Sabater, M.C.; Vila, J.; et al. Antioxidant effect of virgin olive oil in patients with stable coronary heart disease: A randomized, crossover, controlled, clinical trial. Atherosclerosis 2005, 181, 149-158. [CrossRef] [PubMed]

17. Marrugat, J.; Covas, M.-I.; Fitó, M.; Schröder, H.; Miró-Casas, E.; Gimeno, E.; López-Sabater, M.C.; de la Torre, R.; Farré, M. SOLOS Investigators Effects of differing phenolic content in dietary olive oils on lipids and LDL oxidation-a randomized controlled trial. Eur. J. Nutr. 2004, 43, 140-147. [CrossRef]

18. EFSA Panel on Dietetic Products, Nutrition and Allergies (NDA) Scientific Opinion on the substantiation of health claims related to polyphenols in olive. EFSA J. 2011, 9, 2033.

19. EFSA Panel on Dietetic Products, Nutrition and Allergies (NDA) Scientific Opinion on the substantiation of a health claim related to polyphenols in olive. EFSA J. 2012, 10, 2848.

20. EFSA Panel on Dietetic Products, Nutrition and Allergies (NDA) Safety of hydroxytyrosol as a novel food pursuant to Regulation (EC) No 258/97. EFSA J. 2017, 15, 4728.

21. Britton, J.; Davis, R.; O Connor, K. Chemical, physical and biotechnological approaches to the production of the potent antioxidant hydroxytyrosol. Appl. Microbiol. Biotechnol. 2019, 103, 5957-5974. [CrossRef] [PubMed]

22. Martínez-Domínguez, E.; de la Puerta, R.; Ruiz-Gutiérrez, V. Protective effects upon experimental inflammation models of a polyphenol-supplemented virgin olive oil diet. Inflamm. Res. 2001, 50, 102-106. [PubMed]

23. Sánchez-Fidalgo, S.; Villegas, I.; Aparicio-Soto, M.; Cárdeno, A.; Rosillo, M.Á.; González-Benjumea, A.; Marset, A.; López, Ó.; Maya, I.; Fernández-Bolaños, J.G.; et al. Effects of dietary virgin olive oil polyphenols: Hydroxytyrosyl acetate and 3, 4-dihydroxyphenylglycol on DSS-induced acute colitis in mice. J. Nutr. Biochem. 2015, 26, 513-520.

24. Fabiani, R.; De Bartolomeo, A.; Rosignoli, P.; Servili, M.; Montedoro, G.F.; Morozzi, G. Cancer chemoprevention by hydroxytyrosol isolated from virgin olive oil through G1 cell cycle arrest and apoptosis. Eur. J. Cancer Prev. 2002, 11, 351-358. [CrossRef] [PubMed]

25. Baci, D.; Gallazzi, M.; Cascini, C.; Tramacere, M.; De Stefano, D.; Bruno, A.; Noonan, D.M.; Albini, A. Downregulation of Pro-Inflammatory and Pro-Angiogenic Pathways in Prostate Cancer Cells by a Polyphenol-Rich Extract from Olive Mill Wastewater. Int. J. Mol. Sci. 2019, 20, 307. [CrossRef]

26. Rajasekar, J.; Perumal, M.K.; Vallikannan, B. A critical review on anti-angiogenic property of phytochemicals. J. Nutr. Biochem. 2019, 71, 1-15. [CrossRef] [PubMed]

27. Monti, M.C.; Margarucci, L.; Tosco, A.; Riccio, R.; Casapullo, A. New insights on the interaction mechanism between tau protein and oleocanthal, an extra-virgin olive-oil bioactive component. Food Funct. 2011, 2, 423-428. [CrossRef]

28. Tasset, I.; Pontes, A.J.; Hinojosa, A.J.; de la Torre, R.; Túnez, I. Olive oil reduces oxidative damage in a 3-nitropropionic acid-induced Huntington's disease-like rat model. Nutr. Neurosci. 2011, 14, 106-111. [CrossRef]

29. Weinstock-Guttman, B.; Baier, M.; Park, Y.; Feichter, J.; Lee-Kwen, P.; Gallagher, E.; Venkatraman, J.; Meksawan, K.; Deinehert, S.; Pendergast, D.; et al. Low fat dietary intervention with omega-3 fatty acid supplementation in multiple sclerosis patients. Prostaglandins Leukot. Essent. Fatty Acids 2005, 73, 397-404. [CrossRef]

30. Angeloni, C.; Malaguti, M.; Barbalace, M.C.; Hrelia, S. Bioactivity of Olive Oil Phenols in Neuroprotection. Int. J. Mol. Sci. 2017, 18, 2230. [CrossRef]

31. Liu, Z.; Sun, L.; Zhu, L.; Jia, X.; Li, X.; Jia, H.; Wang, Y.; Weber, P.; Long, J.; Liu, J. Hydroxytyrosol protects retinal pigment epithelial cells from acrolein-induced oxidative stress and mitochondrial dysfunction. J. Neurochem. 2007, 103, 2690-2700. [CrossRef] [PubMed] 
32. Zhu, L.; Liu, Z.; Feng, Z.; Hao, J.; Shen, W.; Li, X.; Sun, L.; Sharman, E.; Wang, Y.; Wertz, K.; et al. Hydroxytyrosol protects against oxidative damage by simultaneous activation of mitochondrial biogenesis and phase II detoxifying enzyme systems in retinal pigment epithelial cells. J. Nutr. Biochem. 2010, 21, 1089-1098. [CrossRef] [PubMed]

33. Hagiwara, K.; Goto, T.; Araki, M.; Miyazaki, H.; Hagiwara, H. Olive polyphenol hydroxytyrosol prevents bone loss. Eur. J. Pharmacol. 2011, 662, 78-84. [CrossRef] [PubMed]

34. D'Angelo, S.; Manna, C.; Migliardi, V.; Mazzoni, O.; Morrica, P.; Capasso, G.; Pontoni, G.; Galletti, P.; Zappia, V. Pharmacokinetics and metabolism of hydroxytyrosol, a natural antioxidant from olive oil. Drug Metab. Dispos. 2001, 29, 1492-1498. [PubMed]

35. Christian, M.S.; Sharper, V.A.; Hoberman, A.M.; Seng, J.E.; Fu, L.; Covell, D.; Diener, R.M.; Bitler, C.M.; Crea, R. The toxicity profile of hydrolyzed aqueous olive pulp extract. Drug Chem. Toxicol. 2004, 27, 309-330. [CrossRef] [PubMed]

36. Soni, M.G.; Burdock, G.A.; Christian, M.S.; Bitler, C.M.; Crea, R. Safety assessment of aqueous olive pulp extract as an antioxidant or antimicrobial agent in foods. Food Chem. Toxicol. 2006, 44, 903-915. [CrossRef] [PubMed]

37. Auñon-Calles, D.; Canut, L.; Visioli, F. Toxicological evaluation of pure hydroxytyrosol. Food Chem. Toxicol. 2013, 55, 498-504. [CrossRef]

38. Gordon, M.H.; Paiva-Martins, F.; Almeida, M. Antioxidant activity of hydroxytyrosol acetate compared with that of other olive oil polyphenols. J. Agric. Food Chem. 2001, 49, 2480-2485. [CrossRef]

39. Torres de Pinedo, A.; Peñalver, P.; Rondón, D.; Morales, J.C. Efficient lipase-catalyzed synthesis of new lipid antioxidants based on a catechol structure. Tetrahedron 2005, 61, 7654-7660. [CrossRef]

40. Trujillo, M.; Mateos, M.; de Teran, L.C.; Espartero, J.L.; Cert, R.; Jover, M.; Alcudia, F.; Bautista, J.; Cert, A.; Parrado, J. Lipophilic Hydroxytyrosyl Esters. Antioxidant Activity in Lipid Matrices and Biological Systems. J. Agric. Food Chem. 2006, 54, 3779-3785. [CrossRef]

41. Rodríguez, G.; Lama, A.; Jaramillo, S.; Fuentes-Alventosa, J.M.; Guillén, R.; Jiménez-Araujo, A.; Rodríguez-Arcos, R.; Fernández-Bolaños, J. 3,4-Dihydroxyphenylglycol (DHPG): An Important Phenolic Compound Present in Natural Table Olives. J. Agric. Food Chem. 2009, 57, 6298-6304. [CrossRef] [PubMed]

42. Rodríguez, G.; Rodríguez, R.; Fernández-Bolaños, J.; Guillén, R.; Jiménez, A. Antioxidant activity of effluents during the purification of hydroxytyrosol and 3,4-dihydroxyphenyl glycol from olive oil waste. Eur. Food Res. Technol. 2007, 224, 733-741. [CrossRef]

43. Medina, E.; de Castro, A.; Romero, C.; Brenes, M. Comparison of the Concentrations of Phenolic Compounds in Olive Oils and Other Plant Oils: Correlation with Antimicrobial Activity. J. Agric. Food Chem. 2006, 54, 4954-4961. [CrossRef] [PubMed]

44. Amini, A.; Liu, M.; Ahmad, Z. Understanding the link between antimicrobial properties of dietary olive phenolics and bacterial ATP synthase. Int. J. Biol. Macromol. 2017, 101, 153-164. [CrossRef] [PubMed]

45. Aparicio-Soto, M.; Sánchez-Fidalgo, S.; González-Benjumea, A.; Maya, I.; Fernández-Bolaños, J.G.; Alarcón-de-la-Lastra, C. Naturally Occurring Hydroxytyrosol Derivatives: Hydroxytyrosyl Acetate and 3,4-Dihydroxyphenylglycol Modulate Inflammatory Response in Murine Peritoneal Macrophages. Potential Utility as New Dietary Supplements. J. Agric. Food Chem. 2015, 63, 836-846. [CrossRef] [PubMed]

46. Bernini, R.; Crisante, F.; Barontini, M.; Tofani, D.; Balducci, V.; Gambacorta, A. Synthesis and structure/antioxidant activity relationship of novel catecholic antioxidant structural analogues to hydroxytyrosol and its lipophilic esters. J. Agric. Food Chem. 2012, 60, 7408-7416. [CrossRef]

47. Villanova, L.; Villanova, L.; Fasiello, G.; Merendino, A. Process for the Recovery of Tyrosol and Hydroxytyrosol from Oil Mill Wastewaters and Catalytic Oxidation Method in Order to Convert Tyrosol in Hydroxytyrosol. US7427358 (B2), 23 September 2008.

48. Capasso, R.; Evidente, A.; Avolio, S.; Solla, F. A Highly Convenient Synthesis of Hydroxytyrosol and Its Recovery from Agricultural Waste Waters. J. Agric. Food Chem. 1999, 47, 1745-1748. [CrossRef]

49. Giebel, J.M.; Zaar, A.; Schäfer, R.; Al-Harrasi, A.; Csuk, R. Facile access to oleuropein and hydroxytyrosol from Ligustrum vulgare-A plant material growing all over Eurasia. Mediterr. J. Chem. 2018, 7, 217-222.

50. Gambacorta, A.; Tofani, D.; Bernini, R.; Migliorini, A. High-Yielding Preparation of a Stable Precursor of Hydroxytyrosol by Total Synthesis and from the Natural Glycoside Oleuropein. J. Agric. Food Chem. 2007, 55, 3386-3391. [CrossRef] 
51. Villanova, L.; Villanova, L.; Fasiello, G.; Merendino, A. Process for the Recovery of Tyrosol and Hydroxytyrosol from Oil Mill Wastewaters and Catalytic Oxidation Method in Order to Convert Tyrosol in Hydroxytyrosol. US20090023815 (A1), 2 January 2009.

52. Gambacorta, A.; Tofani, D.; Migliorini, A. High-Yielding Synthesis of Methyl Orthoformate-Protected Hydroxytyrosol and Its Use in Preparation of Hydroxytyrosyl Acetate. Molecules 2007, 12, 1762-1770. [CrossRef]

53. Ziosi, P.; Paolucci, C.; Santarelli, F.; Tabanelli, T.; Passeri, S.; Cavani, F.; Righi, P. A Two-Step Process for the Synthesis of Hydroxytyrosol. Chem. Sus. Chem. 2018, 11, 2202-2210. [CrossRef] [PubMed]

54. Breunninger, M.; Joray, M.; Breuninger, M. Process for the Preparation of Hydroxytyrosol. WO2008107109 (A1), 12 September 2008.

55. Yang, Z.; Tan, F.; Wong, H. Process for Production of Hydroxytyrosol Using Organometallic Compounds. WO2012006783 (A1), 19 January 2012.

56. Zhao, S.; Ma, X.; Liu, X.; Ren, Y.; Liu, Y.; Geng, C.; Deng, Y.; Zhang, N.; Kong, X.; Feng, G.; et al. Improved Method of Hydroxytyrosol Synthesizing Process. CN108164398(A), 15 June 2018.

57. Bernini, R.; Mincione, E.; Barontini, M.; Crisante, F. Convenient Synthesis of Hydroxytyrosol and Its Lipophilic Derivatives from Tyrosol or Homovanillyl Alcohol. J. Agric. Food Chem. 2008, 56, 8897-8904. [CrossRef] [PubMed]

58. Bovicelli, P.; Antonioletti, R.; Mancini, S.; Causio, S.; Borioni, G.; Ammendola, S.; Barontini, M. Expedient Synthesis of Hydroxytyrosol and its Esters. Synth. Commun. 2007, 37, 4245-4252. [CrossRef]

59. Piersanti, G.; Retini, M.; Espartero, J.L.; Madrona, A.; Zappia, G. An efficient, economical synthesis of hydroxytyrosol and its protected forms via Baeyer-Villiger oxidation. Tetrahedron Lett. 2011, 52, 4938-4940. [CrossRef]

60. Tuck, K.L.; Tan, H.-W.; Hayball, P.J. Synthesis of Tritium-Labeled Hydroxytyrosol, a Phenolic Compound Found in Olive Oil. J. Agric. Food Chem. 2000, 48, 4087-4090. [CrossRef] [PubMed]

61. Pouységu, L.; Sylla, T.; Garnier, T.; Rojas, L.B.; Charris, J.; Deffieux, D.; Quideau, S. Hypervalent iodine-mediated oxygenative phenol dearomatization reactions. Tetrahedron 2010, 66, 5908-5917. [CrossRef]

62. Bernini, R.; Mincione, E.; Crisante, F.; Barontini, M.; Fabrizi, G. A novel use of the recyclable polymer-supported IBX: An efficient chemoselective and regioselective oxidation of phenolic compounds. The case of hydroxytyrosol derivatives. Tetrahedron Lett. 2009, 50, 1307-1310. [CrossRef]

63. Joray, M.; Breuninger, M. Process for the Preparation of Phenolic Compounds. WO2007009590 (A1), 25 January 2007.

64. Bernini, R.; Mtncione, E.; Barontini, M.; Crisante, F. Method for Preparing Hydroxytyrosol Derivatives and Hydroxytyrosol. WO2008110908 (A1), 18 September 2008.

65. Yang, Z.; Tan, F.; Wong, H.; Hanselmann, P. Process for Preparing Hydroxytyrosol. WO2012003625 (A1), 12 January 2012.

66. Schmid, L.; Zolinger, D.; Zaragoza, F. Method for Preparation of Hydroxytyrosol. WO2017149017 (A1), 8 September 2017.

67. Plastina, P.; Benincasa, C.; Perri, E.; Fazio, A.; Augimeri, A.; Poland, M.; Witkamp, R.; Meijerink, R. Identification of hydroxytyrosyl oleate, a derivative of hydroxytyrosol with anti-inflammatory properties, in olive oil by-products. Food Chem. 2009, 279, 105-113. [CrossRef]

68. Botta, G.; Bizzarri, B.M.; Garozzo, A.; Timpanaro, R.; Bisignano, B.; Amatore, D.; Palamara, A.T.; Nencioni, L.; Saladino, R. Carbon nanotubes supported tyrosinase in the synthesis of lipophilic hydroxytyrosol and dihydrocaffeoyl catechols with antiviral activity against DNA and RNA viruses. Bioorg. Med. Chem. 2015, 23, 5345-5351. [CrossRef]

69. Grasso, S.; Siracusa, L.; Spatafora, C.; Renis, M.; Tringali, C. Hydroxytyrosol lipophilic analogues: Enzymatic synthesis, radical scavenging activity and DNA oxidative damage protection. Bioorg. Chem. 2007, 35, 137-152. [CrossRef]

70. Sakakura, A.; Pauze, M.; Namiki, A.; Funakoshi-Tago, M.; Tamura, H.; Hanaya, K.; Higashibayashi, S.; Sugai, T. Chemoenzymatic synthesis of hydroxytyrosol monoesters and their suppression effect on nitric oxide production stimulated by lipopolysaccharides. Biosci. Biotechnol. Biochem. 2019, 83, 185-191. [CrossRef] [PubMed]

71. Alcudia, F.; Cert, A.; Espartero, J.L.; Mateos, R.; Trujillo, M. Method of Preparing Hydroxytyrosol Esters, Esters thus Obtained and Use of Same. WO2004/005237 (A1), 15 January 2004. 
72. Alcudia Gonzalez, F.; Cert Ventul, A.; Espartero Sanchez, J.L.; Mateo Briz, R.; Trujillo Perez-Lanzac, M. Method of Preparing Hydroxytyrosol Esters, Esters thus Obtained and Use of Same. EP1541544 (A1), 15 June 2015.

73. Geelings, A.; Leon, E.L.-H.; Morales, J.C.; Puerta, J.B.; Lopez, J.H. Natural Products and Derivatives Thereof for Protection against Neurodegenerative Diseases. US20030236202 (A1), 25 December 2003.

74. Benigni, J.D.; Verbiscar, A.J. The Synthesis of Two New Metabolites of Catecholamines: 3,4-Dihydroxyphenylethyleneglycol and 4-Hydroxy-3-methoxyphenylethyleneglycol1. J. Med. Chem. 1963, 6, 607-608. [CrossRef] [PubMed]

75. Song, Y.; Lin, X.; Kang, D.; Li, X.; Zhan, P.; Liu, X.; Zhang, Q. Discovery and characterization of novel imidazopyridine derivative CHEQ-2 as a potent CDC25 inhibitor and promising anticancer drug candidate. Eur. J. Med. Chem. 2014, 82, 293-307. [CrossRef] [PubMed]

76. Balan, A.M.; .Florea, O.; Moldoveanu, C.; Zbancioc, G.; Iurea, D.; Mangalagiu, I.I. Diazinium salts with dihydroxyacetophenone skeleton: Syntheses and antimicrobial activity. Eur. J. Med. Chem. 2009, 44, 2275-2279. [CrossRef] [PubMed]

77. Chang, Y.-A.; Ares, J.; Anderson, K.; Sabol, B.; Wallace, R.A.; Farooqui, T.; Uretsky, N.; Miller, D.D. Dopamine agonists: Effects of charged and uncharged analogs of dopamine. J. Med. Chem. 1987, 30, 214-218. [CrossRef] [PubMed]

78. Okamoto, K.; Watanabe, M.; Kawada, M.; Goto, G.; Ashida, Y.; Oda, K.; Yajima, A.; Imada, I.; Morimoto, H. Synthesis of Quinones having Carboxy- and Hydroxy-Alkyl Side Chains, and Their Effects on Rat-Liver Lyposomal Membrane. Chem. Pharm. Bull. 1982, 30, 2797-2819. [CrossRef]

79. Cooper, C.B.; Blair, K.T.; Jones, C.S.; Minich, M.L. Synthesis and in vitro antibacterial activities of novel conformationally restricted hygromycin A analogues. Bioorg. Med. Chem. Lett. 1997, 7, 1747-1752. [CrossRef]

80. Talipov, M.R.; Navale, T.S.; Hossain, M.M.; Shukla, R.; Ivanov, M.V.; Rathore, R. Dihedral-Angle-Controlled Crossover from Static Hole Delocalization to Dynamic Hopping in Biaryl Cation Radicals. Angew. Chem. Int. Ed. 2017, 56, 266-269. [CrossRef]

81. Xu, Q.M.; Liu, Y.L.; Li, X.R.; Feng, Y.L.; Yang, S.L. Two New Phenylglycol Derivatives Isolated from Syringa reticulata var. mandshurica and Their Antifungal Activities. Chem. Pharm. Bull. 2009, 57, 863-866. [CrossRef]

Sample Availability: Samples of the compounds 2, 3, 4, 5, 6, 7, 8, 9 are available from the authors.

(C) 2019 by the authors. Licensee MDPI, Basel, Switzerland. This article is an open access article distributed under the terms and conditions of the Creative Commons Attribution (CC BY) license (http://creativecommons.org/licenses/by/4.0/). 